\title{
ESTÉTICA DAS GARÇAS
}

Leonardo Lima Ribeiro ${ }^{1}$

É regra anunciar que a estética das garças pode ser intuída ao atravessarem límpidos ares, os quais lhe tocam as penas que, por seu lado como asas, intentam acariciar cristalino oceano celeste. Todavia, tal percepção decorre de pífia sensibilidade, cuja condição de possibilidade secou há tempos patente felicidade viril, sob exigência e forma de honestas lágrimas. Eis então a secura estética proporcionada pelos homens de mau gosto.

Primeiramente, a beleza das garças ainda não se efetivou como imagem, porquanto os olhares para elas destinados como prenúncio da escrita não foram ainda capazes de produzi-la (a beleza das garças); talvez em razão de a sua sensibilidade - relativa aos olhares anunciados - decerto não conferir garantia para si na sustentação de própria elasticidade (potência de efetividade). Para tanto, fechar os olhos não é sequer opção, uma vez que através desse delicado gesto apenas teríamos a capacidade de perceber como estamos preenchidos de e por terrores que nos revisitam amiúde, terrores próprios ao passado o qual nos oprime a possibilidade de plasmar beleza. Ao contrário da época de Baudelaire, hoje não podemos mais extrair flores do mal, sob forma de poesia ou ensaio. Segue então o pretérito de nós próprios, turbulência onírica que nos arrasta para todos os lados no bojo das angústias que demarcam a nostalgia como dimensão interna: pressão do espírito sobre o próprio espírito, que voltando-se para si intenta exprimir refluxo, resíduos descompassados no registro das dores da carne que os encarna.

Por outro lado, talvez pudéssemos insinuar pontuar a beleza das garças caso as próprias garças se encarregassem da missão, abandonando hodiernos hábitos de espécie, como os de circundar montanhas e assentar-se de bico nos lagos à procura dos frágeis peixes. Aqui, não há possibilidade de escolha a qual possa minimamente ressoar como prática incipiente da liberdade. Liberdade como escolha seria o mesmo que trazer ao campo das próprias escolhas a iminência da ruptura com os códigos da espécie, zona animal que, sendo passível de se desdobrar em distintos gestos, permitiria direcionar humanos olhos à captura de original beleza. O que também não vem ao caso.

1 Possui graduação em Comunicação Social pela Universidade de Fortaleza (UNIFOR); é especialista em Teorias da Comunicação e da Imagem pela UFC (Universidade Federal do Ceará); é mestre em filosofia (linha de pesquisa: Ética) pela UECE (Universidade Estadual do Ceará). 
Torço para que a brancura dessas aves possa certo dia conduzi-las à desfiguração por meio de que, de modo distinto, garanta-se outro instintivo campo de ação. Gostaria, viciadas garças, que extravasassem, rompessem com as imposições de minha fantasmática imaginação, tanto quanto acharia conveniente que despedaçassem os próprios condicionamentos operadores da interinstintividade imanente a vós. Ao fissurar minha imaginação, os processos reais pelos quais se apresentariam não poderiam ser capturados imediatamente à ocasião para as aventuras dos preconceitos por mim já desenvolvidos, condicionados à deliberação corriqueira da pintura dos mesmos quadros, os quais postulariam sua dignidade (a das garças) enquanto bazófia das minhas verdades. Ao distorcer os instintos com outro afã ou matiz de branco clamor, por outro lado, poderiam autorrevelar peculiar imagem, através de que, em teus nomes, poderia eu pintar não sem angústia as letras de amarga, conquanto voraz, beleza. Sonho ou suponho esperançosamente um dia encontrar distintas aves, cujos instintos não condigam com a imaginação enquanto espelho reflexo, tanto quanto clamo para que minha imaginação se desprenda ou não endosse interna empáfia, análoga ao brutal passado que impõe a cristalização do vivo experienciado e pintado como estátuas da morte que me persegue: sombra que suspira calafrios no cérebro, reverberando sopros de inconsciente sensação no amargurado coração.

Algum dia, decerto hei de observar célebres aves, capazes de, com lâminas acopladas às asas, recortar o mundo ao invés de mansamente circundá-lo, descortinando então sua cortina inerente - a qual estaria a velar os recônditos de insensível vazio; algum dia, hei de observar célebres aves, capazes de, com espadas no entorno do corpo, despedaçar e oprimir homens, reconduzidos aos gemidos e prantos enquanto definitiva catarse da sua maldade, cuja passional alegria, até o momento, ainda lhe serve de máscara ou prisão. As garças serão as únicas a pintar o quadro do mundo despedaçado, com pedaços enfim misturados ao negrume do vazio que lhes honra como causa - o que renderá ao mundo e aos homens a ruptura da carcaça.

Tais aves também poderão ser passíveis de colorir o infinito vazio com o sangue dos homens dispostos no limite de inexorável pranto. O vazio, então pintado de vermelho como couraça ou bruma, terá, em paralelo, seu som original: a cor e o som, o vermelho do sangue e os gritos melódicos da carne, ambos oportunos do morticínio, recobrirão e cantarão o porvir, numa ode de horrores como uma só vibração. Seguir-se-á então a obra de arte pintada às duras penas laminadas de autênticas garças, passíveis de revisitar a beleza 
perdida e imiscuída num breve horizonte. Aqui, à época da morte humana, reencontrar-se-á o vazio colorido, colorido em detrimento de humanos gemidos. Assim o sendo, jazerá sob os temores da presente época o quadro latente, a ser pintado, para o qual as garças se voltarão como empreendimento ou enquanto agentes de produção; um quadro através do qual - arrancando-nos a cabeça e as falsas expectativas - a própria imaginação do homem não somente se libertará de si, mas do passado das torturas históricas que não cessam de se repetir. Apenas desse modo Deus se extraviará, tanto quanto a beleza talhada às custas do sangue, com originalidade, reinará. 